\title{
A STUDY TO COMPARE HYPOLIPIDEMIC EFFECTS OF ALLIUM SATIVUM (GARLIC) ALONE AND IN COMBINATION WITH ATORVASTATIN OR EZETIMIBE IN EXPERIMENTAL MODEL
}

\author{
Sudipta Sil ${ }^{1}$,Uttam Kumar Roy ${ }^{2}$, Supreeti Biswas ${ }^{3}$, Purnendu Mandal ${ }^{4}$, Keya Pal5 \\ ${ }^{1}$ North Bengal Medical College and Hospital, Department of Pharmacology, India \\ ${ }^{2}$ Raiganj Govt. Medical College and Hospital, Department of Pharmacology, India \\ ${ }^{3}$ Burdwan Medical College and Hospital, Department of Pharmacology, India \\ ${ }^{4}$ Raiganj Govt. Medical College and Hospital, Department of Pharmacology, India \\ ${ }^{5}$ Burdwan Medical College \& Hospital, Department Of Biochemistry, India
}

\section{STUDIJA ZA UPOREĐIVANJE HIPOLIPIDEMIJSKIH EFEKATA ALLIUM SATIVUM (BELI LUK) I U KOMBINACIJI SA ATORVASTATINOM ILI EZETIMIBOM U EKSPERIMENTALNOM MODELU \\ Sudipta Si1 ${ }^{1}$,Uttam Kumar Roy ${ }^{2}$, Supreeti Biswas ${ }^{3}$, Purnendu Mandal ${ }^{4}$, Keya Pal5 \\ Medicinski koledž i bolnica Severnog Bengala, Odeljenje za farmakologiju, Indija \\ 2 Vlada Raiganj. Medicinski fakultet i bolnica, Odeljenje za farmakologiju, Indija ${ }^{3}$ Medicinski fakultet $i$ bolnica Burdvan, Odeljenje za farmakologiju, Indija \\ ${ }^{4}$ Vlada Raiganj. Medicinski fakultet i bolnica, Odeljenje za farmakologiju, Indija ${ }^{5}$ Medicinski fakultet i bolnica Burdvan, Odeljenje za biohemiju, Indija}

\section{ABSTRACT}

Background: Dyslipidemia is a major cause of atherosclerosis and atherosclerosis induced conditions. Atorvastatin is an effective drug for dyslipidemia and reduce the risk of cardiovascular morbidity and mortality. Ezetimibe is used as an adjunct to statins hypercholesterolemia. Garlic is known for the hypolipidemic effect in traditional medicine. There are very limited studies comparing the additive effects of Allium sativum on atorvastatin and ezetimibe. Aims: To compare the additive hypolipidemic effects of Allium sativum with atorvastatin and ezetimibe. Setting and Design: The experimental study was done in Department of Pharmacology and Biochemistry, Burdwan Medical College, Burdwan from February 2014 - October 2015. Material and Methods: Dyslipidemia rat by (induced by atherogenic diet) were randomized into five groups of six rats in each and each cage was labelled for identification of different groups and treated with drugs (atorvastatin, ezetimibe, garlic homogenate, atorvastatin + garlic homogenate, ezetimibe + garlic homogenate) for twelve weeks and assessment of lipid profiles were done. Change of parameters checked for any significant difference by appropriate statistical tests. Results: Significant TC (Total Cholesterol) \& TG (Triglyceride) concentrations reduction were maximum among ezetimibe group (51\% and 47\%) respectively. LDL (Low Density Lipoprotein) \& VLDL (Very Low-Density Lipoprotein) concentrations reduction were maximum (62\% and 26\%) among combination of atorvastatin and garlic group when compared to other treatment groups. HDL (High Density Lipoprotein) concentration was maximally increased (31\%) among combination ezetimibe and garlic group which was also statistically significant. Conclusion: Garlic have significant hypolipidemic effect when used in combination with atorvastatin and ezetimibe.

Keywords: atorvastatin, dyslipidemia, experimental, ezetimibe, garlic.

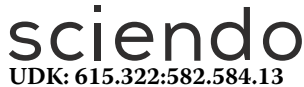

UDK: 615.322:582.584.13 615.272.03
616-008.9-085

Ser J Exp Clin Res 2020; 22 (1): 11-19

DOI: 10.2478/sjecr-2020-0058

\section{SAŽETAK}

Dislipidemija je glavni uzrok ateroskleroze $i$ indukovane ateroskleroze uslovi. Atorvastatin je efikasan lek za dislipidemiju $i$ smanjuje rizik od kardiovaskularnog morbiditeta i mortaliteta. Ezetimib se koristi kao dodatak leku statini hiperholesterolemija. Beli luk je poznat po hipolipidemijskom dejstvu u tradicionalnoj ishrani lek. Postoje vrlo ograničene studije u kojima se upoređuju aditivni efekti Alliuma sativum na atorvastatinu $i$ ezetimibu. Ciljevi: Uporediti aditivne hipolipidemijske efekte Allium sativum sa atorvastatin $i$ ezetimib. Eksperimentalna studija rađena je u Odeljenju za Farmakologija i biohemija, Medicinski koledž Burdvan, Burdvan od februara 2014. do oktobra 2015. godine. Materijal i metode: Dislipidemija pacova (indukovana aterogenom ishranom) randomizirana je u pet grupa od po šest pacova $u$ svakom kavezu, koji su označeni za identifikaciju različitih grupa i lečeni lekovima (atorvastatin, ezetimib, homogenat belog luka, atorvastatin + homogenat belog luka, ezetimib + beli luk homogenat) tokom dvanaest nedelja pri čemu je urađena procena lipidnih profila. Promena parametara proverena na svim značajnim razlikama odgovarajućim statističkim testovima. Rezultati: Značajno smanjenje koncentracije TC (ukupnog holesterola) i TG (triglicerida) bilo je maksimalno među grupama ezetimiba (51\% i 47\%). Smanjenje koncentracije LDL (lipoproteina male gustine) i VLDL (lipoproteina vrlo male gustine) bilo je maksimalno $(62 \%$ i 26\%) u kombinaciji kombinacije atorvastatina $i$ belog luka $u$ poređenju sa drugim lečenim grupama. Koncentracija HDL (lipoprotein visoke gustine) je maksimalno povećana (31\%) među kombinacijama ezetimiba i belog luka, što je takođe bilo statistički značajno. Zaključak: Beli luk ima značajan hipolipidemijski efekat kada se koristi u kombinaciji sa atorvastatinom i ezetimibom.

Ključne reči: atorvastatin, dislipidemija, eksperimentalni, ezetimibe, beli luk.

Corresponding author: Dr.Uttam Kumar Roy Address- Dilip Das Sarani, Hill View Main, PaschimBardhaman, Pin-713304, West Bengal, India Phone numbers: 9434163225 E-mail address: uroy951@gmail.com 


\section{INTRODUCTION}

Dyslipidemia is a major cause of atherosclerosis and atherosclerosis-induced conditions. Both genetic disorders and lifestyle (sedentary behaviour and diets high in calories, saturated fat, and cholesterol) contribute to the dyslipidemias seen in countries around the world ${ }^{1}$.

Atorvastatin competitively inhibits $\mathrm{HMG}-\mathrm{CoA}$ reductase and reduces conversion of HMG-CoA to mevalonate in cholesterol biosynthesis. Ezetimibe used as an adjunct to statins in inhibits absorption of cholesterol (and of plant stanols) from the duodenum.

With the growing interest in screening plants for medicinal activity, reports of hypolipidemic effects of various plants are increasingly encountered in literature. The usage of herbal therapies along with prescription and over the counter medications is increasing day by day. In both animal and human studies, Allium sativum has been reported to lower cholesterol, triglycerides, and change blood lipoproteins. ${ }^{2-12}$

There are gaps in existing knowledge comparing the additive effects of Allium sativum on atorvastatin and ezetimibe in dyslipidemia. Keeping the above facts in view, the present work was undertaken to compare the hypolipidemic effect of Allium sativum alone and in combination with atorvastatin ${ }^{13}$ or ezetimibe in dyslipidemia albino rats induced by atherogenic diet. ${ }^{14-16}$

\section{AIMS}

To establish the hypolipidemic effect of Allium sativum, Atorvastatin and Ezetimibe when used as single agent as well as in combination.

\section{SUBJECTS AND METHODS}

Subjects: Albino rats of both sexes (100-160g) procured from institutional animal house for study.

Drugs and chemicals:

1. Tablet Atorvastatin -Stator-10, Batch no: STA4009 of atorvastatin (Abbott Healthcare Pvt Ltd)

2. Tablet Ezetimibe- Ezentia and Batch no: SKN 0060 of ezetimibe (Sun Pharma Laboratories Ltd)

3. Carboxy methyl cellulose (CMC) sodium salt, medium viscosity (25-350 cps), LOT: S36561201, CAS: 900432-4, S: 22-24/25, F: 3, LobaChemie Private Limited)

4. Garlic homogenate

5. Cholesterol powder (Thermo Fisher Scientific India Pvt Ltd), CAS no: 57-88-5, molar weight: 386.66 , Prod no: 12312, LOT no: 63557005-1

6. Distilled water.

All chemicals used for biochemical analysis of blood parameters were available in Department of Biochemistry.
Study setting: Planning of the protocol and animal experiment was carried (from February 2014 - October 2015) in the Department of Pharmacology, Burdwan Medical College, Burdwan and biochemical part in the Department of Biochemistry.

\section{Ethical considerations: Study was started only after approval from IAEC}

[BMC/AEC/10(2) /2013, DATED 16/12/2013]. The guidelines of the Committee for the Purpose of Control and Supervision on Experiments on Animals (CPCSEA), Animal Welfare Division, Ministry of Environment, Govt. of India for the care and use of the laboratory animals were strictly followed throughout the experimental procedure. Albino rats of either sex with weight of 100 - 160 grams were included in our study. Rampant rats and dietary pattern out of control were excluded from our study.

In accordance with principles of $3 \mathrm{R}^{\prime} \mathrm{s}^{17}$, Replacement was not possible, Reduction with the use of minimum number of experimental animals and Refinement by provision of species appropriate housing and climate conditions (CPCSEA guidelines), minimum invasive procedures, no animals were sacrificed. Care was taken for Rehabilitation.

\section{Preparations and dose calculation}

All drugs administered by gavage feeding. Atherogenic diet/ high fat diet (HFD) was prepared from cholesterol powder. ${ }^{18}$ Cholesterol requirements of each albino rat was calculated at a dose of $125 \mathrm{mg} / \mathrm{kg}$ body weight/day by extrapolation from rabbit dose $\left(0.5 \mathrm{~g} / \mathrm{kg}\right.$ body weight daily) ${ }^{19}$ and total requirement made up in coconut oil. Then $1 \%(\mathrm{w} / \mathrm{v})$ cholesterol solution was prepared by mixing $5 \mathrm{~g}$ dry powder in 500 $\mathrm{ml}$ coconut oil and dose came to $1.25 \mathrm{~mL} / 100 \mathrm{~g} /$ day. Atorvastatin dose calculated by extrapolation from maximum human dose $(80 \mathrm{mg} / \text { day })^{20}$ came to $7.2 \mathrm{mg} / \mathrm{kg}$ body weight/day. ${ }^{19}$ So, when one atorvastatin $(80 \mathrm{mg})$ was mixed with $100 \mathrm{ml}$ $2 \% \mathrm{CMC}$ suspension $(\mathrm{w} / \mathrm{v})$, the dose of atorvastatin for a $100 \mathrm{~g}$ rat was $0.9 \mathrm{ml} /$ day.

Ezetimibe dose calculated by extrapolation from maximum human dose $(10 \mathrm{mg} / \text { day })^{21}$ came to $0.9 \mathrm{mg} / \mathrm{kg}$ body weight/day. So, when one ezetimibe tablet $(10 \mathrm{mg})$ was mixed with $100 \mathrm{ml} 2 \% \mathrm{CMC}$ suspension (w/v), the dose of ezetimibe for a $100 \mathrm{~g}$ rat was $0.9 \mathrm{ml} /$ day.

Preparation of garlic homogenate -The fresh bulbs of Allium sativum were identified and authenticated(Office Of Scientist-'D', Central National Herbarium, Ministry of Environment And Forests, Botanical Survey of India, P.O.-Botanic Garden, Howrah-711103, Government of India, No: BSI/CNH/SD/TECH./2014, dated 19.03.2014).

Garlic 50gm was homogenized in $100 \mathrm{ml}$ of cold distilled water. After centrifugation and filtration, concentration of this garlic preparation was $500 \mathrm{mg} / \mathrm{ml}$, based on the weight 
of the starting material $(50 \mathrm{~g} / 100 \mathrm{ml})^{22}$. Garlic homogenate was administered as a dose of $500 \mathrm{mg} / \mathrm{kg}^{23}$, which came to 0.1 $\mathrm{ml}$ for a 100grat.

\section{Experimental design:}

Albino rats of both sexes (100-160g) procured from institutional animal house were acclimatized for 3 weeks ${ }^{24}$ with free access to food and water (ad libitum). The rooms were equipped with lighting, conditioning, moisture and heat control. After acclimatization, rats were kept on normal diet for 6 weeks. After that period all the rats were kept on overnight fasting with water ad libitum. The fasting rats on the next day properly weighed. The standard cholesterol diet with normal diet and water was administered for 6 weeks to induce dyslipidemia. At the end of the 6 weeks blood was withdrawn (all the rats were kept on overnight fasting with water ad libitum before blood withdrawal) from the tail vein to analyze ${ }^{25}$ lipid profiles to confirm the induction of dyslipidemia.

Now the dyslipidemia rats were randomized (computer generated in Excel) into five groups of six rats in each and treated with drugs orally (along with HFD) accordingly for 12 weeks. ${ }^{26}$ Allocated groups were labeled as Group-I: atorvastatin, Group-II: ezetimibe, Group-III : garlic homogenate, Group-IV : combination of atorvastatin and garlic homogenate and Group- $\mathrm{V}$ : combination of ezetimibe and garlic homogenate. At the end of 12 weeks, blood was withdrawn in the same manner from the tail vein to analyze lipid profiles to observe the hypolipidemic effects of these drugs. Assessment of lipid profiles (TC, TG, LDL, HDL, and VLDL) done (Table 1,2,3).

\section{Measurement of parameters:}

TC, HDL cholesterol and TG concentrations were measured by enzymatic methods. Calculation of LDL cholesterol concentration

$$
\text { LDL cholesterol }=\mathrm{TC}-[\text { HDL cholesterol }+(\mathrm{TG} / 5)]
$$

The VLDL is estimated by dividing the plasma TG by 5 . This formula is reasonably accurate if the fasting TG level does not exceed $200 \mathrm{mg} / \mathrm{dL}$, it cannot be used if the TG level is $>400 \mathrm{mg} / \mathrm{dL}$. Oral feeding and blood collection procedure from lateral tail vein of rat were done properly. ${ }^{27}$ Data analysis was done using Microsoft Excel and IBM SPSS version 17 software.

\section{RESULTS}

In our study, there were 5 groups which were fed high fat diet and were treated with atorvastatin, ezetimibe, garlic, combination of atorvastatin and garlic and combination of ezetimibe \& garlic. As there were different groups and concentrations of TC, TG, HDL, LDL, VLDL were measured after treatment, we analyzed the data with mixed analysis of variance (ANOVA), as the primary purpose of mixed ANOVA is to understand if there is any interaction between two independent variables on the dependent variable, that is to help us to determine whether there are differences among groups over time. Here one between-subject factor is intervention (5 groups), one within subject factor (time) and six dependent variables those are continuous.

In summary we wished to know whether the concentrations differ significantly over time to different interventions (between groups). There was a statistically significant interaction between the intervention and time on lipid profiles. As we had a statistically significant interaction, reporting the main effects could be misleading and we wanted to determine the difference between groups at each level of time and within groups (known as simple main effects).

\section{Simple main effect of group (between groups)}

Testing for the simple main effects for group means testing for differences in lipid profiles between groups at each level of time.

\section{Simple main effect of time (within group)}

It means testing for differences in lipid profiles within a group at two different time points.

\section{TOTAL CHOLESTEROL (TC)}

There was a statistically significant interaction between the intervention and time on Total cholesterol concentration, $\mathrm{F}(4,25)=48.097, \mathrm{p}<.05$, partial $\mathrm{n} 2=.885$. So, simple main effects were done.

\section{Simple main effect of group (between groups)}

There was a statistically significant difference in total cholesterol concentration between different groups after drug treatment, $\mathrm{F}(4,25)=836.714, \mathrm{p}<.05$, partial $\mathrm{n} 2=.993$.

Total cholesterol concentration was increased from ezetimibe group $(124.17 \pm 2.93)$ to atorvastatin + garlic group (134.17 \pm 1.84$)$, atorvastatin group (146.33 \pm 6.59$)$, ezetimibe + garlic group $(207 \pm 1.27)$ and garlic group $(212$ \pm 2.28 ) in that order. Games Howell post-hoc analysis (as there was no homogeneity of variances) revealed that this increase was statistically significant for all groups.

\section{Simple main effect of time (within group)}

There was a statistically significant effect of time on total cholesterol concentration for all the groups and for all the group's total cholesterol concentration was significantly reduced after treatment.(Table 1)

\section{TRIGLYCERIDE (TG)}

There was a statistically significant interaction between the intervention and time on Triglyceride concentration, F (4, $25)=87.256, \mathrm{p}<.05$, partial $\mathrm{n} 2=.933$. So, simple main effects were done. There was a statistically significant difference in Triglyceride concentration between different groups after drug treatment, $\mathrm{F}(4,25)=318.944, \mathrm{p}<.05$, partial $\mathrm{n} 2=$ 
981.Triglyceride concentration was increased from ezetimibe group $(117.33 \pm 1.21)$ to atorvastatin + garlic group $(117.50 \pm 1.52)$, atorvastatin group $(136.33 \pm 5.68)$, ezetimibe + garlic group $(157.83 \pm 1.47)$ and garlic group $(171.33 \pm 4.08)$, in that order .Games Howell post-hoc analysis (as there was no homogeneity of variances) revealed that this increase was statistically significant among all groups except among ezetimibe and atorvastatin plus garlic group.

\section{Simple main effect of time (within group)}

There was a statistically significant effect of time on triglyceride concentration for all the groups and for all the groups, triglyceride concentration was significantly reduced after treatment. (Table 1, Figure 2)

Table 1. Change in Cholesterol and Triglyceride (mg/dl)

\begin{tabular}{|c|c|c|c|c|c|c|}
\hline & \multicolumn{2}{|c|}{ CHOLESTEROL } & \multirow[t]{2}{*}{$\begin{array}{l}\text { Percentage } \\
\text { reduction }\end{array}$} & \multicolumn{2}{|c|}{ TRIGLYCERIDE } & \multirow[t]{2}{*}{$\begin{array}{c}\text { Percentage } \\
\text { reduction }\end{array}$} \\
\hline & PRE & POST & & PRE & POST & \\
\hline Atorvastatin & $255.17 \pm 19.09$ & $\begin{array}{l}146.33 \pm 6.59 \\
P=0.016\end{array}$ & 43 & $226.83 \pm 7.17$ & $\begin{array}{l}136.33 \pm 5.68 \\
P=0.015\end{array}$ & 40 \\
\hline Ezetimibe & $251.67 \pm 13.47$ & $\begin{array}{l}124.17 \pm 2.93 \\
\mathrm{P}=0.001\end{array}$ & 51 & $220.33 \pm 1.86$ & $\begin{array}{l}117.33 \pm 1.21 \\
\mathrm{P}=0.001\end{array}$ & 47 \\
\hline Garlic & $252.50 \pm 13.11$ & $\begin{array}{l}212 \pm 2.28 \\
\mathrm{P}=0.032\end{array}$ & 16 & $222.17 \pm 3.97$ & $\begin{array}{l}171.33 \pm 4.08 \\
\mathrm{P}=0.048\end{array}$ & 23 \\
\hline Atorvastatin + Garlic & $264.33 \pm 20.38$ & $\begin{array}{l}134.17 \pm 1.84 \\
\mathrm{P}=0.001\end{array}$ & 49 & $221.50 \pm 2.43$ & $\begin{array}{l}117.50 \pm 1.52 \\
\mathrm{P}=0.001\end{array}$ & 47 \\
\hline Ezetimibe + Garlic & $259 \pm 12.81$ & $\begin{array}{l}207 \pm 1.27 \\
\mathrm{P}=0.031\end{array}$ & 20 & $224.17 \pm 6.68$ & $\begin{array}{l}157.83 \pm 1.47 \\
\mathrm{P}=0.042\end{array}$ & 30 \\
\hline $\begin{array}{l}\text { P value } \\
\text { Between group }\end{array}$ & 0.141 & $<0.001$ & & 0.201 & $<.001$ & \\
\hline
\end{tabular}

Figure 1. Study flow chart

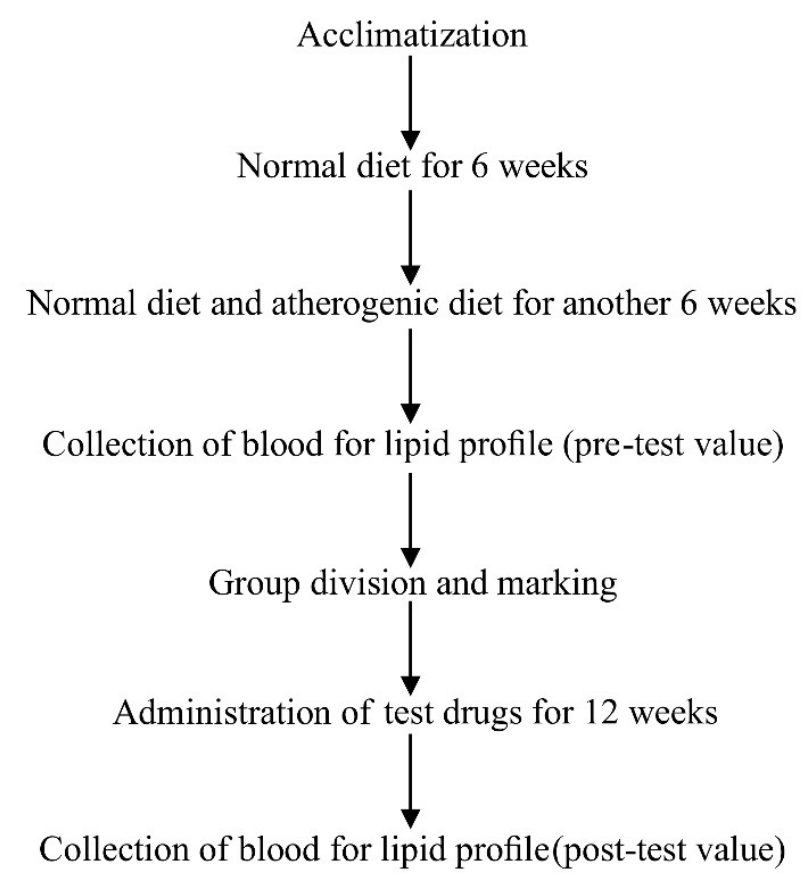

\section{HIGH DENSITY LIPOPROTEIN (HDL)}

There was a statistically significant interaction between the intervention and time on HDL concentration, $F(4,25)=$ $34.308, \mathrm{p}<.05$, partial $\mathrm{n} 2=.469$. So, simple main effects were done.

\section{Simple main effect between groups group}

There was a statistically significant difference in HDL concentration between different groups after drug treatment, $\mathrm{F}(4,25)=12.33, \mathrm{p}<.05$, partial $\mathrm{n} 2=.664$.

HDL concentration was decreased from ezetimibe + garlic group $(52 \pm 1.41)$ to atorvastatin + garlic group $(49.67 \pm$ $1.37)$, garlic group ( $49 \pm 1.67)$, ezetimibe group ( $48 \pm 1.41)$, and atorvastatin group $(46.17 \pm 1.60)$ in that order.

Tukey HSD post-hoc analysis (as there was homogeneity of variances) revealed that this decrease was statistically significant among

1) atorvastatin group and garlic group,

2) atorvastatin group and atorvastatin plus garlic group,

3) atorvastatin group and ezetimibe plus garlic group,

4) ezetimibe group and ezetimibe plus garlic group and

5) garlic group and ezetimibe plus garlic group. 


\section{Simple main effect of time}

There was a statistically significant effect of time on HDL concentration for all the groups and for all the groups HDL concentration was significantly increased after treatment.

Table 2. Change in $\mathrm{HDL}(\mathrm{mg} / \mathrm{dl})$

\begin{tabular}{lccc}
\hline & \multicolumn{2}{c}{ HDL } & $\begin{array}{c}\text { Percentage } \\
\text { change }\end{array}$ \\
\hline Atorvastatin & PRE & POST & \\
Ezetimibe & $39.50 \pm 3.08$ & $\begin{array}{c}46.17 \pm 1.6 \\
\mathrm{P}=0.049 \\
48 \pm 1.41 \\
\mathrm{P}=0.04\end{array}$ & 14 \\
Garlic & $37.17 \pm 2.48$ & $\begin{array}{c}49 \pm 1.67 \\
\mathrm{P}=0.040\end{array}$ & 21 \\
$\begin{array}{l}\text { Atorvastatin } \\
\text { +Garlic }\end{array}$ & $38.50 \pm 3.27$ & $49.67 \pm 1.37$ & 22 \\
\hline $\begin{array}{l}\text { Ezetimibe } \\
\text { +Garlic }\end{array}$ & $38.67 \pm 3.01$ & $\mathrm{P}=0.04$ & 31 \\
\hline $\begin{array}{l}\text { P value } \\
\text { Between group }\end{array}$ & $35.83 \pm 2.23$ & $52 \pm 1.41$ & \\
\hline
\end{tabular}

Figure 2. Change in Biochemical Parameters

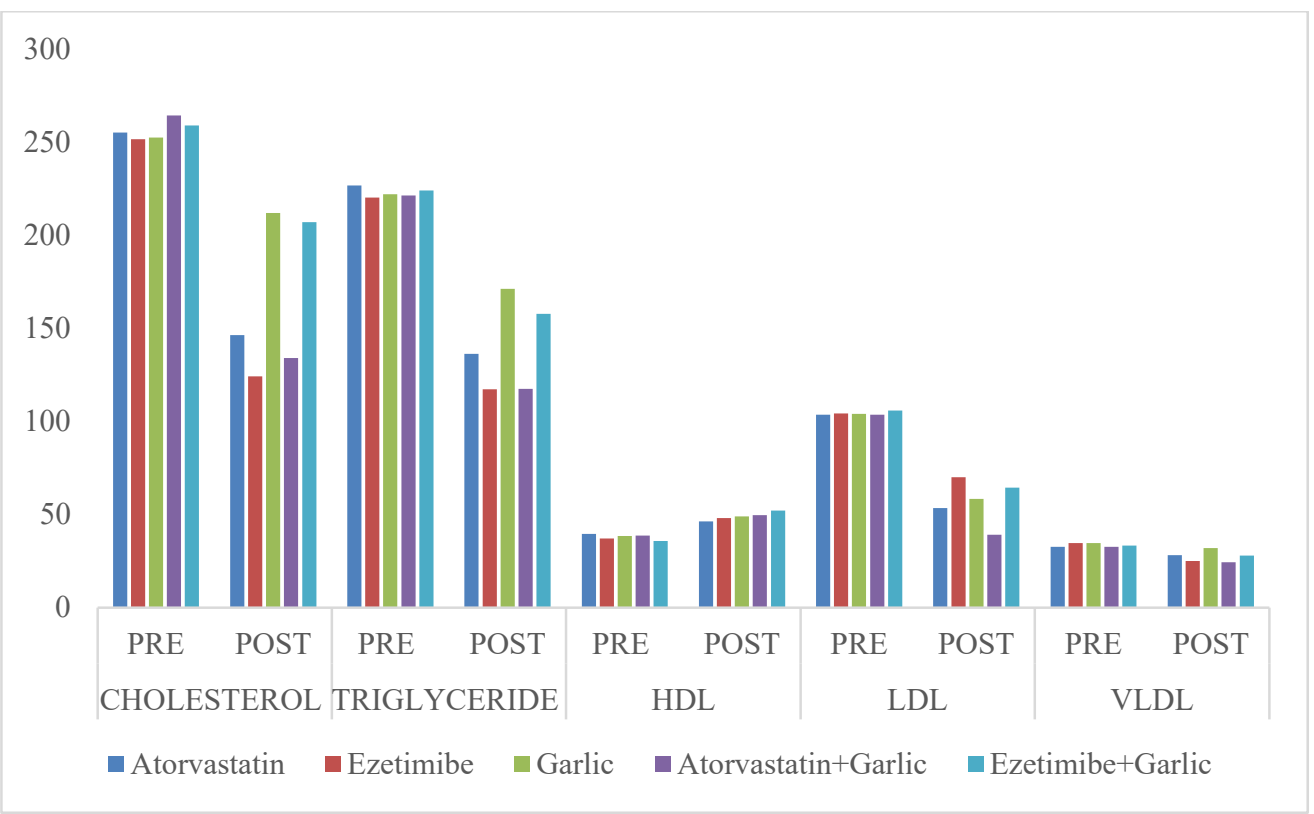

\section{LOW DENSITY LIPOPROTEIN (LDL)}

There was a statistically significant interaction between the intervention and time on LDL concentration, $\mathrm{F}(4,25)=$ $44.721, \mathrm{p}<.05$, partial $\mathrm{n} 2=.877$. So, simple main effects were done.

\section{Simple main effect between groups}

There was a statistically significant difference in LDL concentration between different groups after drug treatment, $\mathrm{F}(4,25)=56.051, \mathrm{p}<.05$, partial $\mathrm{n} 2=.90$.

LDL concentration was increased from atorvastatin + garlic group $(39 \pm 2.53)$ to atorvastatin group $(53.33 \pm 6.56)$, 
garlic group $(58.33 \pm 1.21)$, ezetimibe + garlic group $(64.33$ $\pm 1.37)$ and ezetimibe group $(70 \pm 4.73)$ in that order.

Games Howell post-hoc analysis (as there was no homogeneity of variances) revealed that this increase was statistically significant among all groups except among 1) atorvastatin group and garlic group, 2) ezetimibe group and ezetimibe plus garlic group.

\section{Simple main effect of time}

There was a statistically significant effect of time on LDL concentration for all the groups and for all the groups LDL concentration was significantly reduced after treatment. (Table 3, Figure 2 )

Table 3. Change in LDL and VLDL(mg/dl)

\begin{tabular}{|c|c|c|c|c|c|c|}
\hline & \multicolumn{2}{|c|}{ LDL } & \multirow{2}{*}{$\begin{array}{l}\text { Percent- } \\
\text { age } \\
\text { reduction }\end{array}$} & \multicolumn{2}{|c|}{ VLDL } & \multirow{2}{*}{$\begin{array}{l}\text { Percent- } \\
\text { age } \\
\text { reduction }\end{array}$} \\
\hline & PRE & POST & & PRE & POST & \\
\hline Atorvastatin & $103.50 \pm 2.43$ & $\begin{array}{l}53.33 \pm 6.56 \\
\mathrm{P}=0.001\end{array}$ & 48 & $32.67 \pm 0.81$ & $28.17 \pm 2.79$ & 14 \\
\hline Ezetimibe & $104.17 \pm 2.14$ & $\begin{array}{l}70 \pm 4.73 \\
\mathrm{P}=0.014\end{array}$ & 33 & $34.67 \pm 2.16$ & $\begin{array}{l}25 \pm 0.89 \\
\mathrm{P}=0.041\end{array}$ & 28 \\
\hline Garlic & $104 . \pm 1.41$ & $\begin{array}{l}58.33 \pm 1.21 \\
\mathrm{P}=0.001\end{array}$ & 44 & $34.67 \pm 2.16$ & $\begin{array}{l}31.83 \pm 1.17 \\
\mathrm{P}=0.053\end{array}$ & 8 \\
\hline $\begin{array}{l}\text { Atorvastatin } \\
+ \text { Garlic }\end{array}$ & $103.50 \pm 2.43$ & $\begin{array}{l}39 \pm 2.53 \\
\mathrm{P}=0.001\end{array}$ & 62 & $32.67 \pm 0.82$ & $\begin{array}{l}24.33 \pm 2.25 \\
\mathrm{P}=0.041\end{array}$ & 26 \\
\hline $\begin{array}{l}\text { Ezetimibe } \\
\text { +Garlic }\end{array}$ & $105.83 \pm 1.3$ & $\begin{array}{l}64.33 \pm 1.37 \\
\mathrm{P}=0.015\end{array}$ & 39 & $33.17 \pm 0.75$ & $\begin{array}{l}27.83 \pm 1.47 \\
\mathrm{P}=0.048\end{array}$ & 16 \\
\hline $\begin{array}{l}\text { P value } \\
\text { Between groups }\end{array}$ & 0.271 & $<0.001$ & & 0.634 & $<0.001$ & \\
\hline
\end{tabular}

\section{VERY LOW-DENSITY LIPOPROTEIN (VLDL)}

There was a statistically significant interaction between the intervention and time on VLDL concentration, $F(4,25)$ $=7.659, \mathrm{p}<.05$, partial $\mathrm{n} 2=.551$. So, simple main effects were done.

\section{Simple main effect of group}

There was a statistically significant difference in VLDL concentration between different groups after drug treatment, $\mathrm{F}(4,25)=15.549, \mathrm{p}<.05$, partial $\mathrm{n} 2=.713$.

VLDL concentration was increased from atorvastatin + garlic group $(24.33 \pm 2.25)$ to ezetimibe group $(25 \pm .89)$, ezetimibe + garlic group $(27.83 \pm 1.47)$, atorvastatin group $(28.17 \pm 2.79)$ and garlic group $(31.83 \pm 1.17)$ in that order.

Games Howell post-hoc analysis (as there was no homogeneity of variances) revealed that this increase was statistically significant among 1) ezetimibe group and garlic group, 2) ezetimibe group and ezetimibe plus garlic group, 3) garlic group and atorvastatin plus garlic group.

\section{Simple main effect of time}

There was a statistically significant effect of time on VLDL concentration for all the groups and for all the groups VLDL concentration was significantly reduced after treatment. (Table 3, Figure 2).

\section{DISCUSSION}

Garlic is well known in traditional and folklore medicine for its hypolipidemic effect. Many in vitro and in vivo studies revealed organosulphur compound of Garlic cause inhibition of the hepatic activities of lipogenic and cholesterogenic enzymes that are thought to be the genesis for dyslipidemias, increased excretion of cholesterol and suppression of LDLoxidation. ${ }^{28-30}$

There are very limited studies ${ }^{14,15,16}$ comparing the additive effects of Allium sativum on these 2 drugs (atorvastatin and ezetimibe). The present work was undertaken to compare the hypolipidemic effect of Allium sativum alone and in combination with atorvastatin or ezetimibe in albino dyslipidemia rats (induced by atherogenic diet). After treating with different drugs all parameters (TC, TG, HDL, LDL and VLDL) were recorded and compared with revised baseline values obtained after giving high fat diet. Here we found that, these values were significantly reduced compared to revised baseline values (HDL was increased) and there was significant difference among all the group.

Atorvastatin $(7.2 \mathrm{mg} / \mathrm{kg}$ body weight/day) was able to significantly reduce TC (43\%), TG (40\%), LDL (48\%), VLDL (14\%) and increase HDL (14\%) after 12 weeks of drug treatment in animal models. Our result was supported by various previous studies. Kumar DS et al had showed that atorvastatin $(1.2 \mathrm{mg} / \mathrm{kg}$ body weight $)$ had significantly reduced TC, TG, LDL, VLDL and increased HDL level after 9 
weeks of treatment in animal models. The same type of result was also shown by Krause BR and Newton RS in another study. Rajyalakshmi G et al had showed that plasma TC, TG and LDL levels were significantly reduced, and HDL levels were increased after treatment with atorvastatin in animal models ${ }^{31-33}$. Significant reduction in the level of serum cholesterol, triglyceride, LDL, VLDL and increase in HDL level by HFD+ standard atorvastatin drug was shown by Rajendran Rand Krishnakumar E. The same result was also shown in few another studies where atorvastatin was used $1 \mathrm{mg} / \mathrm{kg}$ body weight and $10 \mathrm{mg} / \mathrm{kg}$ body weight ${ }^{34-37}$.

In our study we had found that, ezetimibe $(0.9 \mathrm{mg} / \mathrm{kg}$ body weight/day) was able to significantly reduce TC (51\%), TG (47\%), LDL (33\%), VLDL (28\%) and increase HDL $(23 \%)$ after 12 weeks of drug treatment in animal models . Mohammadi A et al had shown in a study that chow + $0.005 \%(\mathrm{w} / \mathrm{w})$ Ezetimibe Compared with hypercholesterolemic control rats significantly decreased LDL $(\mathrm{P}<0.05)$ and TC $(\mathrm{P}<0.05)$ after one-month treatment. ${ }^{13}$ The results of many experiments have shown that ezetimibe decline LDL by about $20 \%$ when administered alone. ${ }^{22}$ Studies have shown that ezetimibe decrease the levels of serum triglyceride by 1.7 to $9.4 \%$, but this reduction was not noticeable always. $^{15}$

Garlic homogenate was able to significantly reduce TC (16\%), TG (23\%), LDL (44\%), VLDL (8\%) and increase HDL (21\%) after 12 weeks of drug treatment in animal models in our study. This is also supported by many other studies. Yeh YY et al had showed that hypocholesterolemia effect of water-soluble sulfur compounds of garlic is due to the inhibition of cholesterol synthesis pathway, while the inhibition by lipid-soluble extracts of garlic results from the strong toxic properties of this lipid-extract. They also proved that water extract inhibited cholesterol synthesis more than methanol and petroleum extractable fraction.$^{38}$ Elmahdi B et al had showed in a study that adding $8 \%$ raw garlic to rat atherogenic diet (diet containing $2 \%$ cholesterol), declined serum total cholesterol and LDL levels and increased HDL .${ }^{39}$ Aouadi et al. also, showed that addition of $10 \%$ fresh garlic to atherogenic diet (diet containing 2\% cholesterol) led to significant reduction in LDL levels, and raised HDL levels in rat model.${ }^{40}$ In a study, HDL significantly increased in garlic extract-treated animals when compared with normal chow diet. A study ${ }^{38}$ was conducted to evaluate the effectiveness of aged black garlic (ABG) extract in alleviating obesity and hyperlipidemia, and regulating antioxidant properties in rats fed high-fat diet by Kim I et al and they had shown that administration of ABG extract had improved the body weight gain and dyslipidemia through the suppression of body lipid profiles and antioxidant defense system. ${ }^{41}$

Atorvastatin plus garlic group were able to significantly reduce TC (49\%), TG (47\%), LDL (62\%), VLDL (26\%) and increase HDL (22\%) after 12 weeks of drug treatment in animal models in our study. In a study it was shown that after one-month treatment significant reduction in total cholesterol levels in rats treated with either Garlic Extract or AT
( $80 \mathrm{mg} / \mathrm{kg}$ ) when compared to control group. Similarly, Concurrent administration of atorvastatin with garlic extract significantly decreased total cholesterol level compared to control group. Moreover, combined administration of atorvastatin and garlic extract produced a synergistic effect on the reduction of total cholesterol levels. This synergistic effect was observed at lower dose level of AT $(20 \mathrm{mg} / \mathrm{kg})$ while it is lost at higher dose level of AT $(80 \mathrm{mg} / \mathrm{kg})$ which had contradicted our study result. However, no significant change in triglyceride levels was observed in garlic extract-treated rats (which had also contradicted our study) whereas, administration of AT (20 and $80 \mathrm{mg} / \mathrm{kg}$ ) either alone or in combination with GE produced significant decrease in triglycerides levels compared to control group, which had supported our study result. ${ }^{42}$

Ezetimibe plus garlic group were able to significantly reduce TC (20\%), TG (30\%), LDL (39\%), VLDL (16\%) and increase HDL (31\%) after 12 weeks of drug treatment in animal models in our study. Maheswari G et al had shown in an animal study that the combination of ezetimibe $(30 \mu \mathrm{g} / \mathrm{kg})$ with garlic extract $(10 \mathrm{mg} / \mathrm{kg})$ resulted in lowering of serum total body cholesterol (12\%), triglycerides $(30 \%)$, LDL $(33 \%)$, VLDL $(21 \%)$ along with increase in serum HDL (46\%) after treatment which indicated that garlic extract augmented hypolipidemic effect of ezetimibe.$^{14}$ This result was similar to our result but augmented hypolipidemic effect was not properly found in our study.

Mohammadi A et al had shown in a study that serum levels of LDL and TC significantly decreased in ezetimibe $(p<0.05)$, garlic $(p<0.05)$, and much more in combination of garlic and ezetimibe groups $(\mathrm{p}<0.001)$. TG and VLDL markedly decreasedingarlicandcombinationofgarlicandezetimibegroups $(\mathrm{p}<0.05)$ while change of $\mathrm{TG}$ and VLDL in ezetimibe-treated animals were not significant. In their study they had used $4 \%(\mathrm{w} / \mathrm{w})$ garlic powder and $0.005 \%(\mathrm{w} / \mathrm{w})$ ezetimibe ${ }^{15}$

In our study we had found that, after drug treatment given, significant TC \& TG concentrations reduction were maximum among ezetimibe group, significant LDL \& VLDL concentrations reduction were maximum among combination of atorvastatin and garlic group when compared to other treatment groups. HDL concentration was maximally increased among combination ezetimibe and garlic group which was also statistically significant.

Our study had certain limitations- Blood samples were drawn only at one point of time after the treatment, short study duration.

\section{CONCLUSION}

Biochemical parameters (TC, TG, LDL, and VLDL) could be effectively reduced and HDL could be increased after treating the animals with atorvastatin, ezetimibe, garlic homogenate, combination of atorvastatin and garlic homogenate, combination of ezetimibe and garlic homogenate. The 
maximum effectivity in such reduction with ezetimibe for TC and TG. For LDL \& VLDL, combination of atorvastatin and garlic homogenate was most effective. The maximum effectivity in increase of HDL was noted with combination of ezetimibe and garlic homogenate. In summary, Garlic extract augmented hypolipidemic effect of ezetimibe and atorvastatin. Moreover, there is maximum effect with ezetimibe on HDL and with atorvastatin on LDL \&VLDL, though study with various dose ranges is required

There remains a scope for future studies with larger sample size and longer duration. It is recommended for future extrapolation in human after toxicity study.

\section{REFERENCES}

1. Thomas PB. Drug Therapy for Hypercholesterolemia and Dyslipidemia. In: Laurence LB, Bruce AC Björn CK, editors. Goodman \& Gilman's The Pharmacological Basis of Therapeutics. 12th ed. SunDieogo: McGraw Hill; 2012.p. 877-906.

2. Gu B, You J, Li YP and Yuan QL. Supplementation of Enteric-coated Ginger and Garlic Essence Tablet Improved Blood Lipid Profile in Rats Fed High-fat Diet and Hyperlipidemic Subjects. Food Sci. Technol. Res. 2011; 17(5): 409-14.

3. Maheswari G. Investigation of effect of garlic extract on the hypolipidemic effect of ezetimibe. Pharmacologyonline. 2011; 2: 291-95.

4. Gupta V. Hypolipidemic Effect of Fenugreek and Garlic on Experimentally Induced Hyperlipidemia in Rabbits: A Randomized Control Trial. International Journal of Basic and Applied Physiology; 2(1): 193.

5. Aka LO. The effects of dietary supplementation of Allium sativum on some vital biochemical parameters in male Albino rats. Sokoto Journal of Veterinary Sciences. 2010; 8(1): 26-30.

6. Shrivastava A, Chaturvedi U, Singh SV, Saxena JK, Bhatia G. A mechanism based pharmacological evaluation of efficacy of Allium sativum in regulation of dyslipidemia and oxidative stress in hyperlipidemic rats. Asian Journal of Pharmaceutical and Clinical Research. 2012; 5(3): 123-26.

7. Ebesunun $\mathrm{MO}$ et al. The effect of garlic on plasma lipids and lipoproteins in rats fed on high cholesterol enriched diet. Biokemistri. 2007; 19(2): 53-58.

8. Tanamai J, Veeramanomai S, Indrakosas N. The Efficacy of cholesterol-lowering action and side effects of Garlic enteric coated tablets in man. J Med Assoc Thai 2004; 87(10): 1156-61.

9. Turner B, Molgaard C, Markmann P. Effect of Garlic (Allium Sativum) powder tablet on serum lipid, blood pressure and arterial stiffness in normolipidemic volunteers: a randomized double blind, placebo-controlled trial. Br J Nutr 2004; 92:701-6

10. Peleg A, Hershcocivi T, Lipa r, Anbar r, Redler M, Beigel Y. Effect of Garlic on lipid profiles psychopathologic parameters in people with mild to moderate hypercholesterolemia. Isr Med Assoc J 2003; 5(9): 637-40.
11. Superko HR, Krauss RM. Garlic powder, effect on plasma lipids, postprandial lipemia, low density lipoprotein particle size, high density lipoprotein subclass distribution and lipoprotein (a). J Am Coll Cardiol 2000; 35(2): 321-6.

12. Syed Mohammed BasheeruddinAsdaq, "Antioxidant and Hypolipidemic Potential of Aged Garlic Extract and Its Constituent, S-Allyl Cysteine, in Rats," EvidenceBased Complementary and Alternative Medicine, vol. 2015, Article ID 328545, 7 pages, 2015. https://doi.org/10.1155/2015/328545.

13. Gosaina S. Hypolipidemic effect of ethanolic extract from the leaves of hibiscus sabdariffa 1. in hyperlipidemic rats. Acta PoloniaePharmaceutica ñ Drug Research. 2010; 67: 179-84.

14. Maheshwari G, Pandey SP, Chandel HS, Chadoker A, Keservani RK, Sharma AK. Investigation of effect of garlic extract on the hypolipidemic effect of ezetimibe. Pharmacologyonline. 2011; 2: 291-95.

15. Mohammadi A. The In Vivo Biochemical and Oxidative Change by Garlic and Ezetimibe Combination in Hypercholesterolemic Mice. International Research Journal of Biological Sciences. 2014; 3(4):47-51.

16. Hamed, M \&Hassanein, Nahed\& Ali, Azza\&Elnahhas, Toqa. (2010). An Experimental Study on the Therapeutic Efficacy of the Combined Administration of Herbal Medicines with Atorvastatin against Hyperlipidemia in Rats. 6. 1730-1744.

17. Burden N, Chapman K, Sewell F, Robinson V. Pioneering better science through the 3Rs: an introduction to the national centre for the replacement, refinement, and reduction of animals in research (NC3Rs). J Am Assoc Lab Anim Sci. 2015;54(2):198-208.

18. Sampathkumar MT, Kasetti RB, Nabi SA, Sudarshan PR, Swapna S, Apparao C. Antihyperlipidemic and antiatherogenic activities of Terminalia pallida Linn. fruits in high fat diet-induced hyperlipidemic rats. J Pharm Bioallied Sci. 2011;3(3):449-452. doi:10.4103/09757406.84464

19. Bagchi C, Tripathi SK, Hazra A, Bhattacharya D. Evaluation of Hypolipidemic Activity of Premnaintegrifolia Linn. Bark in Rabbit Model. Pharmbit.2008; 18(2): 149.

20. Pfizer Ireland Pharmaceuticals. Lipitor (atorvastation) [package insert] .US Food and Drug Administration. Website.https://www.accessdata.fda.gov/drugsatfda_docs/label/2009/020702s056lbl.pdf. Revised November 2019.Accessed February 19, 2020.

21. Merck/Schering-Plough Pharmaceuticals. Zetia (ezetimibe) [package insert] .US Food and Drug Administration. Website.https://www.accessdata.fda.gov/drugsatfda_docs/label/2007/021445s018lbl.pdf.Revised June 2007. Accessed February 19, 2020.

22. Emmanuel UC and James O. Comparative Effects of Aqueous Garlic (Allium sativum) and Onion (Allium cepa) extracts on Some Haematological and Lipid Indices of Rats. Annual Review \& Research in Biology. 2011; 1(3): 37-44. 
23. Asdaq SMB, Inamdar MN, Asad M. Effect of conventional antihypertensive drugs on hypolipidemic action of garlic in rats. Indian Journal of Experimental Biology. 2009; 47: 176-81.

24. Ministry of Environment, Forest and Climate Change Government of India.Compendium of CPCSEA. New Delhi; CPCSEA; 2018. p. 62.

25. University of Veterinarian and Animal Resouces. SOP: Blood Collection from the Tail Vein in Rats. [Cited 1 December 2019]. Avaialable from URL:

26. https://ouv.vt.edu/content/dam/ouv_vt_edu/sops/smallanimal-biomedical/sop-rat-blood-collection-tailvein.pdf

27. Reddy GD, Reddy GA, Rao GS, and Kumar MV. Pharmacokinetic interaction of garlic and atorvastatin in dyslipidemic rats. Indian Journal of Pharmacology. 2012 Mar- Apr; 44(2): 246-52.

28. The University of British Colombia. Sops, Policies, And Guidelines. [Cited 1 December 2019]. Avaialable from URL: https://animalcare.ubc.ca/sites/default/files/documents/ACC-2012 Tech09\%20Oral\%20Dosing\%20\%28 Gavage $\% 29 \% 20$ in $\% 20$ the $\% 20$ Mouse $\% 20$ and $\% 20$ Rat $\% 29 \% 20$ Updated $\% 20 \mathrm{Feb} \% 202015 \% 20 \mathrm{fnal}$-cc $\% 2 \mathrm{C} \%$ 20ka.pdf.

29. Yu-Yan Yeh, Lijuan Liu, Cholesterol-Lowering Effect of Garlic Extracts and Organosulfur Compounds: $\mathrm{Hu}-$ man and Animal Studies, The Journal of Nutrition, Volume 131, Issue 3, March 2001, Pages 989S-993S, https://doi.org/10.1093/jn/131.3.989S.

30. Yang C, Li L, Yang L, Lü H, Wang S, Sun G. Anti-obesity and Hypolipidemic effects of garlic oil and onion oil in rats fed a high-fat diet. NutrMetab (Lond). 2018; 15:43. Published 2018 Jun 20. doi:10.1186/s12986-0180275-X.

31. Sun YE, Wang W, Qin J. Anti-hyperlipidemia of garlic by reducing the level of total cholesterol and low-density lipoprotein: A meta-analysis. Medicine (Baltimore). 2018;97(18): e0255. doi:10.1097/MD.00000000000 10255

32. Kumar DS, Muthu AK, Smith AA, Manavalan R. Hypolipidemic effects of various effects of Whole plant of MucunaPruriens (Linn) in rat fed with high fat diet. European Journal of Biological Sciences. 2010; 2(2): 3238.

33. Krause BR, Newton RS. Lipid-lowering activity of atorvastatin and lovastatin in rodent species: triglyceride-lowering in rats correlates with efficacy in LDL animal models. Atherosclerosis. 1995 Oct; 117(2): 237-44.

34. Rajyalakshmi G, Reddy A, Rajesham V. A Comparative Antihyperlipidemic Activity of Atorvastatin with Simvastatin in Rats. The Internet Journal of Pharmacology. 2008; 6(2).

35. Rajendran R and Krishnakumar E. Hypolipidemic Activity of Chloroform Extract of Mimosa pudica Leaves. AJMB. October-December 2010; 2(4): 215-22.

36. Pillai KK, Chidambaranathana N, Halitha MM, Jayaprakasha S and Narayana N. Hypolipidemic activity of ethanolic extract of leaves of cnidoscoluschayamansa in hyperlipidemic models of wistar albino rats. Acta Chim. Pharm. Indica. 2012; 2(1): 24- 31.

37. Girija K, Lakshman K, Chandrika PU. Hypolipidemic effect of amaranthuscaudatus 1. in triton wr-1339 induced hyperlipidemic rats. Pharmacologyonline. 2011; 1: 84-91.

38. Eerike M, Arunachalam R, Yeddula VR, Konda VGR, Prasanth CR. Evaluation of Hypolipidemic Activity of Ethanolic and Aqueous Extracts of Fragaria Vesca in High Fat Diet Induced Hyperlipidemia in Rats. Int. J. Pharm. Sci. Rev. Res. September - October 2014; 28(2): 191-96.

39. Yeh Y.Y. and Liu L, Cholesterol-lowering effect of garlic extracts and organosulfur compounds: human and animal studies, J Nutr. 2001; 131(3s), 989S-93S.

40. Elmahdi B., Khalil MM and Abulgasim AI. The Effect of Fresh Crushed Garlic Bulbs (Allium sativum) on Plasma Lipids in Hypercholesterolemic Rats, Journal of Animal and Veterinary Sciences. 2008; 3: 15-19.

41. Aouadi R. Effect of fresh garlic on lipid metabolism in male rats. Nutrition Research. 2000; 273-280.

42. Kim I et al. The beneficial effects of aged black garlic extract on obesity and hyperlipidemia in rats fed a highfat diet. Journal of Medicinal Plants Research. 2011; 5(14): 3159-68.

43. Heeba GH, Abd-Elghany MI. Effect of combined administration of ginger (Zingiber officinale Roscoe) and atorvastatin on the liver of rats. Phytomedicine. 2010; 17(14):1076-81. 